\title{
Exit velocity: Is there truth in the commonly-held belief that grades for undergraduate students tend to improve from Year 2 to Year 3 ? A case study
}

\author{
Mark Betteney \\ University of Greenwich
}

This case study is being composed in December 2014 and is written in response to unexpected but repeated questions from many of the Year 2 and Year 3 students on the programme which I lead (BA, Primary Education, with Qualified Teacher Status). Amongst my third-year students, there has been a rather unhelpful outbreak of speculative projected calculation with regard to the degree classification that they might expect. Those with lowerthan-anticipated grades during their second year are convinced that a 'good' degree is already beyond them and that, without a 'good' degree, employment opportunities will be severely diminished.

I have tried to reassure these students that, from my experience of leading Progression and Award Boards (PABs), it is the norm for student grades to accelerate (i.e. the trend is for Year 3 grades to be better than those in Year 2, in spite of the increase in academic demands). I have also explained to them that Year 2 comprises only $25 \%$ of their degree and Year 3, 75\%, and that, as a result, this acceleration is a good thing. One particularly anxious student asked me: 'How much better are the Year 3 grades, on average?' I could not answer that question; indeed, I realised that I did not even know for certain that my claim was true.

So, it is to answer that student's question and to satisfy my own curiosity that I have made an analysis of the last four years' PABs data for the final-year students on my programme. Do grades tend to improve from Year 2 to Year 3? The data for my programme hold interesting patterns and show that the answer to that question is: 'Yes... and no.'

\section{Supporting literature}

Before the data is presented, the vocabulary needs to be explored and limited. Here at the University of Greenwich, we refer to the phenomenon of grade progression in the final year as 'exit velocity'. I realise immediately that my assumption that student grades improve from Year 2 to Year 3 has been established in my mind because we have an official name for it. 'Exit Velocity' should not be confused with 'academic momentum', since this latter expression is a technical term, used mainly in America, and refers to the speed at which students complete modular programmes (Attewell \& Scott, 2012). 'Grade inflation' is not at all what this case study is focused upon, since this term is derogatory, suggesting grade awards which do not correspond with a student's ability or performance. That is why, for the purposes of this case study, I shall use the phrase 'exit velocity' to denote an aspect of student progression whereby a student might be identified as achieving better average grades in the final year than in the previous one(s).

The literature surrounding this field is very thin. There are some published sources which focus on the progress, retention and predicted attainment of first year students (Ackerman et al, 2013; Arum and Roksa, 2011; Geiser and Santelices, 2007; Upcraft et al, 2005; Herzog, 2005; Simonite, 2003). Each of these sources is American and each offers either examples of the way one might predict retention, graduation or employment outcomes from pre- 
university or first-year grades or the categorisation of characteristics of pre-university or firstyear students who go on to be academically successful within given criteria. Analysis of such data can tell us much about the efficacy of an institution or can inform an institution's recruitment and selection policy, but does not focus on the specific aspect of academic maturation on which this study is based.

Similarly, there are sources which explore whether different types of learning (e-learning; learning-centred teaching) enhance grade improvement (Bell and Federman, 2013; Mostrom \& Blumberg, 2012). However, despite a diligent search (Swetswise, EBSCO, Google Scholar, Education Research Complete), I have found no article which asks and answers the question that this article poses - whether (and the extent to which) grades for undergraduate students improve from Year 2 to Year 3. This article aims to begin to fill this rather surprising void.

\section{Methodology}

The demographic of the students on my programme needs to be briefly described for readers who teach or study on other programmes and who might therefore make comparison or contrast to their own student body. Across the four years of this study, the proportion of completing male students was consistent, being between 16-18\% (average $17.1 \%$ ). The proportion of completing BME students increased incrementally from $17.1 \%$ in 2010-11 to $19.8 \%$ in $2013-14$. Satisfaction levels were high, with $93 \%$ of students considering the quality of their training to be good or very good (National Student Survey data 2012-14). The average age on completion was 24.1 (10.4\% of students were over 30 , and $4.2 \%$ were over 40 ). The oldest student to complete was 44 . There was no significant incidence of completing male students' being on average older or younger than female ones.

The data from students completing their degrees (with or without Qualified Teacher Status) from 2010 to 2014 were analysed in two ways. The first was by student number (identifying the proportion of students whose results fell into diverse deciles at the end of their second year, and tracking them into the same or a different decile on completion). The second was by average grade (identifying and measuring the extent to which the average grade of a decile cohort of students at the end of its second year increased or decreased on completion). Each year's data are presented separately and then combined.

\section{The data, analysed by student number}

The tables below present the outcomes of the four most recent completed cohorts on the 3Year undergraduate Primary Education with Qualified Teacher Status programme, together with an analysis of each degree-classification cohort's outcomes during its second year. 
Table 1: Degree classifications by student number, 2013-14

\begin{tabular}{|c|c|c|c|c|c|c|}
\hline & \multirow{2}{*}{$\begin{array}{c}\text { Total } \\
\text { awards } \\
\text { in Year } \\
3\end{array}$} & \multicolumn{4}{|c|}{$\begin{array}{l}\text { Number of students, in classification bands at the end of } \\
\text { Year } 2\end{array}$} & \multirow[b]{2}{*}{ Total } \\
\hline & & $70 \%+$ & $60-69 \%$ & $50-59 \%$ & $40-49 \%$ & \\
\hline First & 9 & 3 & 6 & - & - & 9 \\
\hline Upper second & 48 & 2 & 27 & 18 & 1 & 48 \\
\hline Lower second & 38 & - & 3 & 28 & 7 & 38 \\
\hline \multirow[t]{2}{*}{ Third } & 2 & - & - & 1 & 1 & 2 \\
\hline & 97 & & & & & 97 \\
\hline
\end{tabular}

Note how only 3 students averaged more than $70 \%$ at the end of Year 2, and yet 9 students achieved a first class degree at the end of Year 3, showing that 6 students $(66 \%$ of the total achieving a first class degree) made decile improvement from their end-of-Year 2 position. Similarly, of the 48 students who were awarded an upper second, 18 (38\% of them) improved from their $50-59 \%$ decile in Year 2. At first glance, there appears to be truth in the claim about the existence of student exit velocity.

However, things are not so encouraging at the lower end. Of the 38 students who were awarded a lower second, 3 regressed from the $60-69 \%$ band of Year 2 and only 7 (18\% of those achieving a lower second) improved from the $40-49 \%$ band. With only two students awarded a third, no analysis is possible there.

$\underline{2012-13}$

Table 2: Degree classifications by student number, 2012-13

\begin{tabular}{|c|c|c|c|c|c|c|}
\hline & \multirow{2}{*}{$\begin{array}{c}\text { Total } \\
\text { awards } \\
\text { in Year } \\
3\end{array}$} & \multicolumn{4}{|c|}{$\begin{array}{l}\text { Number of students, in classification bands at the end } \\
\text { of Year } 2\end{array}$} & \multirow[b]{2}{*}{ Total } \\
\hline & & $70 \%+$ & $60-69 \%$ & $50-59 \%$ & $40-49 \%$ & \\
\hline First & 13 & 1 & 10 & 2 & 0 & 13 \\
\hline Upper second & 50 & 0 & 28 & 20 & 2 & 50 \\
\hline Lower second & 41 & 0 & 3 & 32 & 6 & 41 \\
\hline Third & 4 & 0 & 0 & 1 & 3 & 4 \\
\hline & 108 & & & & & 108 \\
\hline
\end{tabular}

The same pattern with regard to evidence of exit velocity applies for the 2012-13 completers. In this cohort, only one student averaged more than $70 \%$ at the end of Year 2 and yet 13 students achieved a first class degree on completion. Similarly, of the 50 students who were awarded an upper second, 20 (40\% of them) improved from their 50-59\% decile in Year 2. There is clear evidence that these students experienced exit velocity.

Again, however, things are more stagnant at the lower end. Of the 41 students who were awarded a lower second, only 6 (15\% of them) improved from the $40-49 \%$ band. Of the four 
students awarded a third, three were established there at the end of Year 2 and one regressed (sharply, from an average of 58\%). There is no upward movement here.

$2011-12$

Table 3: Degree classifications by student number, 2011-12

\begin{tabular}{|c|c|c|c|c|c|c|}
\hline & \multirow{2}{*}{$\begin{array}{c}\text { Total } \\
\text { awards } \\
\text { in Year }\end{array}$} & \multicolumn{6}{|l|}{ Number of students, in classification bands at the end } \\
of Year 2 & $\mathbf{5 0 - 5 9 \%}$ & $\mathbf{4 0 - 4 9 \%}$ & Total \\
\cline { 4 - 8 } & 3 & $\mathbf{7 0 \% +}$ & $\mathbf{6 0 - 6 9 \%}$ & $\mathbf{5 0} \%$ & 0 & 8 \\
\hline First & 8 & 7 & 1 & 0 & 0 & 45 \\
\hline Upper second & 45 & 2 & 32 & 11 & 7 & 42 \\
\hline Lower second & 42 & 0 & 6 & 29 & 7 & 8 \\
\hline Third & 8 & 0 & 0 & 1 & & 103 \\
\hline
\end{tabular}

The patterns are less marked in this cohort's data, and the preponderance of final degree classification is more accurately anticipated at the end of Year 2, particularly with regard to first class classifications. However, it can be seen again that the proportion of students who converted from $50-59 \%$ to achieve an Upper second (24\% of them) was higher than the proportion of students who converted from $40-49 \%$ to a Lower second (16\%).

$\underline{2010-11}$

Table 4: Degree classifications by student number, 2010-11

\begin{tabular}{|c|c|c|c|c|c|c|}
\hline & \multirow{2}{*}{$\begin{array}{c}\text { Total } \\
\text { awards } \\
\text { in Year } \\
3\end{array}$} & \multicolumn{4}{|c|}{$\begin{array}{c}\text { Number of students, in classification bands at the end } \\
\text { of Year } 2\end{array}$} & \multirow[b]{2}{*}{ Total } \\
\hline & & $70 \%+$ & $60-69 \%$ & $50-59 \%$ & $40-49 \%$ & \\
\hline First & 12 & 2 & 10 & 0 & 0 & 12 \\
\hline Upper second & 29 & 2 & 19 & 8 & 0 & 29 \\
\hline Lower second & 40 & 0 & 0 & 32 & 8 & 40 \\
\hline \multirow[t]{2}{*}{ Third } & 10 & 0 & 0 & 5 & 5 & 10 \\
\hline & 91 & & & & & 91 \\
\hline
\end{tabular}

For the higher-achieving students, the data for 2010-11 return to the patterns seen in 2012 13 and 2013-14. Only 2 students averaged more than 70\% at the end of Year 2, and yet 12 students achieved a first class degree at the end of Year 3. Of the 29 students who were awarded an upper second, 8 (28\% of them) improved from their $50-59 \%$ decile in Year 2.

Of the 40 students who were awarded a lower second, 8 (20\% of them) improved from the $40-49 \%$ band. The most stark statistic is that, in this cohort, of the 10 students awarded a third (an unusually high number, not seen before or since), 5 were established there at the end of Year 2, and the other 5 regressed. Again, there is no upward movement here, and a sizeable downward pattern. 


\section{The data, analysed by average grade}

The data in tables 1-4 have presented exit velocity as demonstrated by student number. The data can also be analysed by average marks. Tables 5-9 group students by final classification, and identify the average grade for each group at the end of its second year.

2013-14

Table 5: Degree classifications by average grade, 2013-14

\begin{tabular}{|c|c|c|c|}
\hline & $\begin{array}{c}\text { End of Year 3 average } \\
\text { grade }\end{array}$ & $\begin{array}{c}\text { End of Year 2 } \\
\text { average grade }\end{array}$ & Exit velocity (\%age +/-) \\
\hline First & 70.2 & 68.1 & $+2.1 \%$ \\
\hline Upper second & 62.1 & 61.0 & $+1.1 \%$ \\
\hline Lower second & 53.1 & 53.3 & $-0.2 \%$ \\
\hline Third & 48.0 & 45.5 & $-2.5 \%$ \\
\hline
\end{tabular}

The pattern here is clear. There is a gradual weakening of exit velocity, and a linear change can be seen, with diminishing progression in the top two categories and increasing regression in the lower classification from first class to third class.

\section{$\underline{2012-13}$}

The same regression applies in this cohort but the pattern is much stronger. Note the $6.6 \%$ improvement made by the higher-achieving students compared with the $0.7 \%$ average improvement made by those awarded a lower second. The number of students awarded a third is small, but the average grade falls sharply and the data show that every student in this cohort receiving a third class degree regressed from her/his Year 2 average.

Table 6: Degree classifications by average grade, 2012-13

\begin{tabular}{|c|c|c|c|}
\hline & $\begin{array}{c}\text { End of Year 3 average } \\
\text { grade }\end{array}$ & $\begin{array}{c}\text { End of Year 2 } \\
\text { average grade }\end{array}$ & Exit velocity (\%age $+/-)$ \\
\hline First & 71.3 & 64.7 & $+6.6 \%$ \\
\hline Upper second & 63.4 & 60.2 & $+3.2 \%$ \\
\hline Lower second & 55.2 & 54.5 & $+0.7 \%$ \\
\hline Third & 45.5 & 48.8 & $-7.2 \%$ \\
\hline
\end{tabular}

\section{$\underline{2011-12}$}

Above, this cohort does not fit the general pattern in terms of student numbers and, similarly, the pattern of average grade does not quite conform to the norm either. Again, students achieving first class degrees made the most progress and those awarded third class degrees regressed, but there is not a linear regression of exit velocity in this cohort. 
Table 7: Degree classifications by average grade, 2011-12

\begin{tabular}{|c|c|c|c|}
\hline & $\begin{array}{c}\text { End of Year 3 average } \\
\text { grade }\end{array}$ & $\begin{array}{c}\text { End of Year 2 } \\
\text { average grade }\end{array}$ & Exit velocity (\%age $+/-)$ \\
\hline First & 71.3 & 70.3 & $+1.4 \%$ \\
\hline Upper second & 62.6 & 62.1 & $+0.8 \%$ \\
\hline Lower second & 54.8 & 54.1 & $+1.3 \%$ \\
\hline Third & 46.7 & 48.1 & $-2.9 \%$ \\
\hline
\end{tabular}

\section{$\underline{2010-11}$}

The linear pattern seen in 2012-13 and 2013-14 is seen again in the data for this cohort, and the pattern is strong.

Table 8: Degree classifications by average grade, 2010-11

\begin{tabular}{|c|c|c|c|}
\hline & $\begin{array}{c}\text { End of Year 3 average } \\
\text { grade }\end{array}$ & $\begin{array}{c}\text { End of Year 2 } \\
\text { average grade }\end{array}$ & Exit velocity (\%age +/-) \\
\hline First & 71.3 & 68.9 & $+3.5 \%$ \\
\hline Upper second & 64.4 & 62.6 & $+2.8 \%$ \\
\hline Lower second & 53.9 & 53.6 & $+0.5 \%$ \\
\hline Third & 46.2 & 51.0 & $-10.3 \%$ \\
\hline
\end{tabular}

\section{Combined data}

Tables 9 and 10 combine the data for all four year groups.

Table 9: Degree classifications by student number, 2010-11 to 2013-14

\begin{tabular}{|c|c|c|c|c|c|c|}
\hline & \multirow{2}{*}{$\begin{array}{c}\text { Total } \\
\text { awards } \\
\text { in Year } 3\end{array}$} & \multicolumn{4}{|c|}{$\begin{array}{c}\text { Number of students, in classification bands at the end } \\
\text { of Year } 2\end{array}$} & \multirow[b]{2}{*}{ Total } \\
\hline & & $70 \%+$ & $60-69 \%$ & $50-59 \%$ & $40-49 \%$ & \\
\hline First & 42 & 13 & 27 & 2 & 0 & 42 \\
\hline Upper second & 172 & 6 & 106 & 57 & 3 & 172 \\
\hline Lower second & 161 & 0 & 12 & 121 & 28 & 161 \\
\hline \multirow[t]{2}{*}{ Third } & 24 & 0 & 0 & 8 & 16 & 24 \\
\hline & 399 & & & & & 399 \\
\hline
\end{tabular}

Table 9 summarises that, over a four-year period, the data for students in the higherachieving deciles provide clear evidence for the existence of exit velocity. Over the four annual cohorts that this case study has examined, $64 \%$ of the students who secured a first class degree did so by improving from the upper or lower second decile at the end of year 2 . By comparison, during the same four-year period, $33 \%$ of the students securing an upper second did so by improving from the lower second or third class decile and only $17 \%$ of the students securing a lower second did so by improving from the third class decile. 
A consistent linear pattern is also demonstrated by looking at the average grades of the students in the four classifications (Table 10). On average, over the four years, exit velocity has incrementally changed by approximately $1.7 \%$ for each degree classification band.

Table 10: Degree classifications by average grade, 2010-11 to 2013-14

\begin{tabular}{|c|c|c|c|}
\hline & $\begin{array}{c}\text { End of Year 3 average } \\
\text { grade }\end{array}$ & $\begin{array}{c}\text { End of Year 2 } \\
\text { average grade }\end{array}$ & Exit velocity (\%age $+/-)$ \\
\hline First & 71.0 & 67.7 & $+3.3 \%$ \\
\hline Upper second & 63.0 & 61.3 & $+1.7 \%$ \\
\hline Lower second & 54.1 & 54.0 & $+0.1 \%$ \\
\hline Third & 46.7 & 48.4 & $-1.7 \%$ \\
\hline
\end{tabular}

\section{Conclusion}

For two reasons, it is not possible to generalise about student progression from the data of this case study. Firstly, the participant number (399) is not large enough and, secondly, as the students in this study were on a professional programme, there were additional variables at work, which students on non-professional programmes do not experience. If this study were to be replicated for a non-professional programme, it is possible that, just for that reason, the patterns of exit velocity might be significantly different from those represented here.

There are a number of external characteristics and personal circumstances that this study purposely has not taken into account. During their time as undergraduates, students may have experienced health issues and/or financial difficulties. No account has been taken of those students for whom an array of life-style features may have negatively impacted upon their degree classification: those with children (some may have been single parents); those who were holding down part-time jobs; those who experienced complications in their personal lives; those who were living a long distance from the university; those who decided for whatever reason to follow a non-QTS pathway. No extenuating circumstances have been factored in to the data of this study, although a co-authored analysis of the geographical domicile distribution of completing students will be submitted for publication in due course.

Nevertheless, patterns have been revealed in this study's data and three conclusions can be drawn. For the students represented in this study:

1. Exit velocity was likely to be present for students who ultimately secured a lower second class degree, or better.

2. The strength of exit velocity was consistently greater for the higher-performing students.

3. Students awarded a third class degree tended to experience a regression in exit velocity. Deeper analysis of the data for the students achieving a third class degree showed that over the four years of this case study, 19 of the 24 (79\% of them) regressed from their Year 2 average.

The original question that this study sought to explore was: 'Is there truth in the commonlyheld belief that grades for undergraduate students tend to improve from Year 2 to Year 3?' The answer, in this case study, was 'Yes' to various extents for $94 \%$ of the students 
represented, but, for those $6 \%$ for whom the opposite is true, the degree of regression is significant.

\section{Reference list}

Ackerman, P.L., Kanfer, R. and Beier, M.E. (2013) 'Trait complex, cognitive ability, and domain knowledge predictors of baccalaureate success, STEM persistence, and gender differences.' Journal of Educational Psychology, 105(3), 911-927.

Arum, R. and Roksa J. (2011) Academically Adrift. University of Chicago Press: Chicago.

Attewell, P. and Scott, H. (2012) 'What Is Academic Momentum? And Does It Matter?' Educational Evaluation and Policy Analysis, 34(1), 27-44.

Bell, S.B. and Federman, J.E. (2013) 'E-learning in Postsecondary Education.' The Future of Children, 23(1), 165-185.

Geiser S and Santelices V. (2007) 'Validity of high-school grades in predicting students' success beyond the freshman year: High-School Record vs. Standardized Tests as Indicators of Four-Year College Outcomes.' Research \& Occasional Paper Series: CSHE.6.07. University of California: Berkeley.

Herzog, S. (2005) 'Measuring determinants of student return vs. dropout/stopout vs. transfer: A first to second year analysis of new freshman.' Research in Higher Education, 46(8), 883928.

Mostrom, A. and Blumberg, P. (2012) 'Does learning-centred teaching promote grade improvement?' Innovative Higher Education, 37(5), 397-405.

Simonite V. (2003) 'A Longitudinal Study of Achievement in a Modular First Degree Course.' Studies in Higher Education, 28(3), 293-302.

Upcraft, M., Gardner, J.N., and Barefoot, B.O. (2005) Challenging and Supporting the FirstYear Student. Jossey-Bass: San Francisco, CA. 